\title{
Die Jñāta-Erzählungen
}

im sechsten Anga des Kanons der Jinisten.

Von

Dr. Wilhelm Hüttemann.

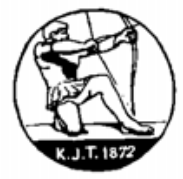

Straßburg

Verlag von Karl J. Trübner

1907. 
M. DuMont Schauberg, Straßburg. 


\section{Dem Andenken}

\section{Wilhelm Volkmars.}


